\title{
ASSESSING THE TOP ELEVEN CHALLENGES FACING THE EXPLORATION AND PRODUCTION INDUSTRY IN NIGERIA: A REVIEW
}

\author{
Okorie E. Agwu', Julius U. Akpabio ${ }^{2}$, Moses G. Akpabio ${ }^{3}$ \\ ${ }^{1,2,3}$ Department of Chemical \& Petroleum Engineering University of Uyo, Uyo. P.M.B. 1017, Uyo, Nigeria \\ demogaz@yahoo.com
}

\begin{abstract}
The Exploration and Production ( $E$ and $P$ ) industry is one complex industry characteristically coloured with boundless risk limits and occasioned by humongous capital requirements which more often than not are scarce in nature. This paper brings to the fore the various challenges that have confronted the $E$ and P industry in Nigeria and the ways the industry has been affected. The top eleven challenges were isolated and discussed to find a common ground in order to bridge existing solution gaps. The choice of the top eleven challenges was in itself a challenge because of the wide spectrum from which to choose - from the very basic to the very complex. To achieve this, data from secondary sources were collected and analyzed using a descriptive approach. An organization of the final list shows that the challenges include four titles on oil facilities, three titles for each of uncertainty and the environment, two titles each of technology, people and government policy and one title for each of demand and insecurity. Two factors were observed to impact negatively on the industry namely; the uncertainty in getting at the oil itself and the uncertainty in the price of oil at a given time. In all, it is observed that revenue decline lies at the heart of the challenge map. However, for each challenge, existing approaches to solving them are presented and useful tips are suggested as to how to improve on the existing solutions. These suggestions are learnings tapped from other areas of the globe where they have proven successful. The ideas presented in this paper if utilized would help indigenous, service companies and the multinational companies involved in the oil \& gas business in Nigeria to stay afloat especially at times that oil prices are plummeting.
\end{abstract}

Keywords: Challenges, E\&P Industry, Oil prices, Uncertainty

\section{INTRODUCTION}

In 1956, upon the discovery of the Oloibiri oilfield, Nigeria's first oilfield of commercial importance, Oloibiri well-1 was drilled and completed by the then Shell D' Arcy Exploration Company. This major oil discovery sparked a massive wave of various foreign oil multinational companies invading Nigeria and acquiring vast tracts of territory in the hope of getting a piece of the action. From then on, several more oilfields were discovered across the country. In 1958 however, Nigeria started commercial production of oil and gas. This production has come with both positive and negative sides. Lines between the positives and negatives of oil and gas exploration and production in Nigeria can be blurry as some have argued that having an oil well located at one's backyard is a death sentence (Bassey, 2001) while others hold the opinion that it has brought a great deal of prosperity after all (Tamuno and Felix, 2006). On a positive note, proceeds from crude oil has over time gradually metamorphosed from being one of the sources of revenue to the Nigerian economy to being the key pivot on which the nation's economy rests. However, a chronicle of the life of the industry and its players from the late 1950s up until now shows that it is one industry that aptly exemplifies the proverbial cat with nine lives. The industry in Nigeria has over time had to battle with numerous challenges some of which it has surmounted and others it is still searching for solutions. Some of the challenges may be generic while others may be peculiar to the Nigerian terrain. For instance, in the United States, Stegemeier (1986) stated: "I don't need to tell you that these are times of turmoil for our industry. From last December to April, we saw crude prices plunge from about $\$ 28$ to $\$ 10$ a barrel -- a 60 percent drop in just four months. As consumers cheered, and short-sighted pundits heaped praise on cheaper oil, we in the petroleum business knew better. America was once again in an energy war - it's third in 13 years". To show that these challenges kept recurring even on a global scale, Cazalot (2007) stated: "We are at a time of dramatic, perhaps unprecedented, change and challenge in the global oil and gas business". He further added that a number of factors, such as changing geopolitical relationships, the emergence of new competitors, changes in supply and demand dynamics, social and environmental pressures, and demographic shifts, are responsible for transforming and reshaping the industry. On the local scene, the views are not different. As reported by Alike (2015) in Thisdaylive Newspaper, a former Minister of Petroleum Resources in Nigeria, Mr. Odein Ajumogobia identified the challenges facing the Nigeria's oil and gas sector, saying that the industry has witnessed dwindling fortunes, especially since 2004 , when oil industry workers and facilities came under incessant and direct attacks by the ex-militants in the Niger Delta. These are just some of the many views on the challenges the industry 
faces. Notice that the observations made by the three personalities mentioned above zeros down to one major negative effect on the industry and that is - revenue decline. The knowledge that the industry is a cost intensive industry given the elephantine figures denominated in billions of dollars that is invested in it shows that any sort of decline in revenue to it would shake its foundation. This view is further buttressed in the words of Bradford (1995) when he said: "Today, resources of the oil and gas industry are pulled in many directions. It takes a major effort to manage the various priorities demanding attention. A company's effectiveness in balancing priorities determines whether it survives." Hence for survival, there is need to critically assess all challenges to the oil and gas industry with a view to bringing them to the barest minimum. This is the main driver for this work. For good reason, a perfect solution to the top eleven challenges of the industry in Nigeria is not a goal of this paper. The reason being that as one seeks perfection, the less likely for one to contribute to the solution of a problem. Rather, the intent and purpose is to provide a few useful tips for improving the status quo. Though some of these tips may sound too simplistic, too complex, too obvious, too quixotic or too obscure, the consolation is that ample references would be provided. Previous works in this area indicate that researchers tend to dwell only on one or two specific challenges as it affects the industry. More often than not, the available researches revolve mainly around oil spills, pipeline vandalism, crude oil theft and gas flaring as seen in Table 1. Consequently, this paper holds the view that a holistic assessment of the challenges of the industry while it is on its feet would mean "fixing the car while the engine is running".

Table 1: Summary catalogue of researches into challenges facing the oil industry in Nigeria [2004 - 2015]

\begin{tabular}{|c|c|c|}
\hline Oil industry challenge & Major investigation done & Researcher(s) (year) \\
\hline $\begin{array}{l}\text { Aging } \\
\text { (pipelines) }\end{array}$ & Tackling pipeline aging through corrosion & Edeko and Mbamalu (2004) \\
\hline Pipeline vandalism & Solutions to oil pipeline vandalism & Brume, F. (2006) \\
\hline Pipeline vandalism & Investigated pipeline vandalization and its effects. & Onuoha, F.C. (2007) \\
\hline Oil spillage and gas flaring & $\begin{array}{l}\text { Impacts of oil spillage and gas flaring on the Population and } \\
\text { distribution of birds in Niger Delta region of Nigeria }\end{array}$ & Idris, R. O. (2007) \\
\hline Oil bunkering & Appraised the oil bunker trade in Nigeria & Onuzuruike, V.I (2008) \\
\hline Pipeline vandalism & X-rayed the dimensions of pipeline sabotage in Nigeria & Onuoha, F.C (2008) \\
\hline Oil spill & Ecological restoration of oil spill sites & Imoobe and Iroro (2009) \\
\hline Oil spill & $\begin{array}{l}\text { Investigated oil spill effects on the physico-chemical } \\
\text { characteristics of riverine areas of Ondo state and their effects } \\
\text { on lives and living in the oil communities }\end{array}$ & Oloruntegbe et. al (2009) \\
\hline Gas flaring & A review of the effects of gas flaring & Ologunorisa, T.E (2009) \\
\hline Gas flaring & Environmental impact of gas flaring and abatement measures & Aghalino, S.O. (2009) \\
\hline $\begin{array}{l}\text { Gas flaring, Oil Spill and } \\
\text { politics }\end{array}$ & $\begin{array}{l}\text { The study examined oil-related environmental externalities } \\
\text { and oil-induced politics in the oil-bearing areas. }\end{array}$ & Babatunde, A. (2010) \\
\hline Crude oil theft / Insecurity & Examined the volatile security situation in the Niger Delta & Badmus, I.A (2010) \\
\hline Oil spill & $\begin{array}{l}\text { Environmental challenges of oil spillage for families in oil } \\
\text { producing areas }\end{array}$ & Egbe and Thompson (2010) \\
\hline Gas flaring & $\begin{array}{l}\text { Effects of prolonged exposure to flared gas on human } \\
\text { hematology }\end{array}$ & Adienbo and Nwafor (2010) \\
\hline $\begin{array}{l}\text { Oil spill \& pipeline } \\
\text { vandalization }\end{array}$ & $\begin{array}{l}\text { The impacts of oil spill incidents and pipeline vandalization to } \\
\text { the public health }\end{array}$ & Aroh et al. (2010) \\
\hline Gas flaring & Adverse effects of gas flaring on the environment & Orimoogunje et al. (2010) \\
\hline Pipeline vandalization & $\begin{array}{l}\text { Examined the effects, the causes, and the manifestation of oil } \\
\text { pipeline vandalization in Niger Delta. }\end{array}$ & Etekpe and Okolo (2010) \\
\hline Gas flaring & Assessed the effect of gas flaring on the environment & Nkwocha \& Pat-Mbano (2010) \\
\hline Gas flaring & $\begin{array}{l}\text { Examined the theoretical framework for gas flaring and its } \\
\text { implication for environmental accounting in the Nigerian } \\
\text { Petroleum Industry. }\end{array}$ & Ayoola, T.J (2011) \\
\hline Oil spill & $\begin{array}{l}\text { Examined the environmental pollution and remediation of oil } \\
\text { spillage in the Nigerian Coastal areas }\end{array}$ & Adelana et.al. (2011) \\
\hline Oil spillage and Gas flaring & Addressing the problem of oil spillage and gas flaring & Benedict, A.O (2011) \\
\hline Gas flaring & Using litigations to stop gas flaring & Ukala, E. (2011) \\
\hline Gas flaring & Factors affecting gas flaring laws in Nigeria & Okafor, O. (2011) \\
\hline Oil spill & Investigated the health implications of oil spillage & Salako et.al. (2012) \\
\hline Oil spillage and Gas flaring & $\begin{array}{l}\text { Influence of oil spillage and gas flaring cost on the life } \\
\text { expectancy rate of the Niger Delta People }\end{array}$ & Effiong \& Etowa (2012) \\
\hline Pipeline Vandalism & How pipeline vandalization and how it affects the oil & Oteh \& Eze (2012) \\
\hline
\end{tabular}




\begin{tabular}{|c|c|c|}
\hline Oil industry challenge & Major investigation done & Researcher(s) (year) \\
\hline & communities in the Niger Delta & \\
\hline Oil spill & Oil spill control and management & Egwu, S.A. (2012) \\
\hline Pipeline Vandalism & $\begin{array}{l}\text { Investigated the level of the causes of pipeline vandalization } \\
\text { and its environmental impacts in the Niger Delta region. }\end{array}$ & Lawal \& Ese (2012) \\
\hline Oil spill & $\begin{array}{l}\text { Assessed the socio-economic effect of environmental } \\
\text { degradation in the Niger Delta }\end{array}$ & Oshwofasa et. al. (2012) \\
\hline Pipeline failures & Ascertaining the causes of pipeline failures & Achebe et al. (2012) \\
\hline Oil spill & $\begin{array}{l}\text { Highlighted some of the existing oil pollution laws in Nigeria, } \\
\text { discussed the current legislations and suggested areas for } \\
\text { improvement }\end{array}$ & Kafada et. al. (2012) \\
\hline Pipeline vandalism & $\begin{array}{l}\text { Recommended best practice for prudent pipeline management } \\
\text { in Nigeria. }\end{array}$ & Udofia \& Joel (2012) \\
\hline Oil spill & $\begin{array}{l}\text { Statistical analysis carried out for oil spillage quantities and } \\
\text { incidence between 1976-2000. }\end{array}$ & Kadafa, A.A (2012) \\
\hline Pipeline vandalism & $\begin{array}{l}\text { Investigated the implications of oil pipeline vandalism for } \\
\text { Nigeria's national security. }\end{array}$ & Okoli and Orinya (2013) \\
\hline Gas flaring & $\begin{array}{l}\text { Studied the contribution of gas flaring in Nigeria to global } \\
\text { warming }\end{array}$ & Audu, E.B (2013) \\
\hline Illegal oil bunkering & $\begin{array}{l}\text { Effect of oil bunkering activities in Niger Delta and its } \\
\text { impacts on the human environment. }\end{array}$ & Nwanolue et al. (2013) \\
\hline Oil spillage and gas flaring & $\begin{array}{l}\text { Socio-Economic problems associated with E \& } \mathrm{P} \text { activities in } \\
\text { the Niger Delta }\end{array}$ & Iwejingi, S.F (2013) \\
\hline $\begin{array}{l}\text { Petrol tanker disaster and } \\
\text { pipeline vandalization }\end{array}$ & $\begin{array}{l}\text { Studied petrol tanker disaster and pipeline vandalization and } \\
\text { their impacts on regional development }\end{array}$ & Oluwatuyi \& Ileri (2013) \\
\hline Gas flaring & Effects of gas flaring & Ajugwo, A.O (2013) \\
\hline Oil spill & Examined the compensation of oil spill victims in Nigeria & Imosemi and Abangwu (2013) \\
\hline Oil spill and gas flaring & $\begin{array}{l}\text { Environmental problems associated with oil spill and gas } \\
\text { flaring }\end{array}$ & Raji and Abejide (2013) \\
\hline Oil spillage and gas flaring & Cost of oil spillage and gas flaring & Udoayang and Etowa (2013) \\
\hline Gas flaring & $\begin{array}{l}\text { Environmental impact analysis of gas flaring (Experimental } \\
\text { analysis) }\end{array}$ & Ubani and Onyejekwe (2013) \\
\hline $\begin{array}{l}\text { Oil spill, gas flaring, } \\
\text { drilling discharges }\end{array}$ & Environmental issues in the $\mathrm{E} \& \mathrm{P}$ operations & Ite et al. (2013) \\
\hline $\begin{array}{l}\text { Demand for petroleum } \\
\text { products }\end{array}$ & $\begin{array}{l}\text { Made a projected energy demand for petroleum products in } \\
\text { Nigeria. }\end{array}$ & Isa et al. (2013) \\
\hline $\begin{array}{l}\text { Oil theft \& pipeline } \\
\text { vandalization }\end{array}$ & $\begin{array}{l}\text { Evaluated the evolution, etiology, causes, nature, extent, } \\
\text { characteristics, legal aspects, trends rationale and modus } \\
\text { operandi of oil theft and pipeline vandalization. }\end{array}$ & Igbinovia, P. E (2014) \\
\hline Gas flaring & Impacts of gas flaring and remedies & $\begin{array}{l}\text { Abdulhakeem and Chinevu } \\
\text { (2014) }\end{array}$ \\
\hline Gas flaring & $\begin{array}{l}\text { Design of gas flaring equipment to minimize the emission of } \\
\text { GHGs }\end{array}$ & Kaladumo and Ideriah (2014) \\
\hline Pipeline vandalism & Automated electronic detection of pipeline vandalism & Chukwujekwu et al. (2014) \\
\hline Gas flaring & Strategies for ending gas flaring in Nigeria & Ibitoye, F.I (2014) \\
\hline Crude oil theft & Analysis of crude oil theft in the political economic context & Ufuoma and Omoruyi (2014) \\
\hline Pipeline Vandalism & Challenge of maintaining effective security against vandalism & Oguntuyi, O. (2014) \\
\hline Crude oil theft & $\begin{array}{l}\text { Examined the cause, operators and effect of oil theft on state } \\
\text { development activities }\end{array}$ & Wilson,G. (2014) \\
\hline Gas flaring & Studied the impact of gas flaring on Niger Delta women & Omeire et. al. (2014) \\
\hline $\begin{array}{l}\text { Petroleum products scarcity } \\
\text { / Demands }\end{array}$ & $\begin{array}{l}\text { Strategic management approaches for minimizing the } \\
\text { occurrence of petrol scarcity }\end{array}$ & Akpan \& Nnamseh (2014) \\
\hline Crude oil theft & $\begin{array}{l}\text { Explained the surge in oil theft in Nigeria from the viewpoint } \\
\text { of ethno political settlement }\end{array}$ & Oyefusi, A. (2014) \\
\hline Crude oil theft & Estimating volumes of stolen crude & Livinus et al. (2014) \\
\hline Corruption & Examined corruption in oil and gas industry in Nigeria and its & Donwa et al. (2015) \\
\hline
\end{tabular}




\begin{tabular}{|l|l|l|}
\hline Oil industry challenge & Major investigation done & Researcher(s) (year) \\
\hline Oil theft & implication for economic growth & \\
\hline & $\begin{array}{l}\text { Examined the methods, actors, causes, impacts of oil theft and } \\
\text { the measures adopted by Nigerian governments to combat oil } \\
\text { theft. }\end{array}$ & Boris, O.H (2015) \\
\hline
\end{tabular}

From Figure 1, it is evident that from 2004 to 2015, the leaning of most researchers tilted towards the gas flaring, oil spill and pipeline vandalism challenges as seen in the percentages. Only a few researchers looked at oil theft since this seemed to be an emerging challenge. Challenges relating to technological gap, government policies, price volatility and dearth of skilled labour as well as aging infrastructure received little or no attention. This research gap provides a motivation for this paper and would ultimately be filled by this work. However, it is worthy to note here that the leaning of most researchers mainly on environmental degradation through oil spill and gas flaring paints a grim portrait of $\mathrm{E}$ and $\mathrm{P}$ activities in Nigeria and the poignant depiction of the environment especially in Ogoni land is one of the telling brushstrokes in that picture.

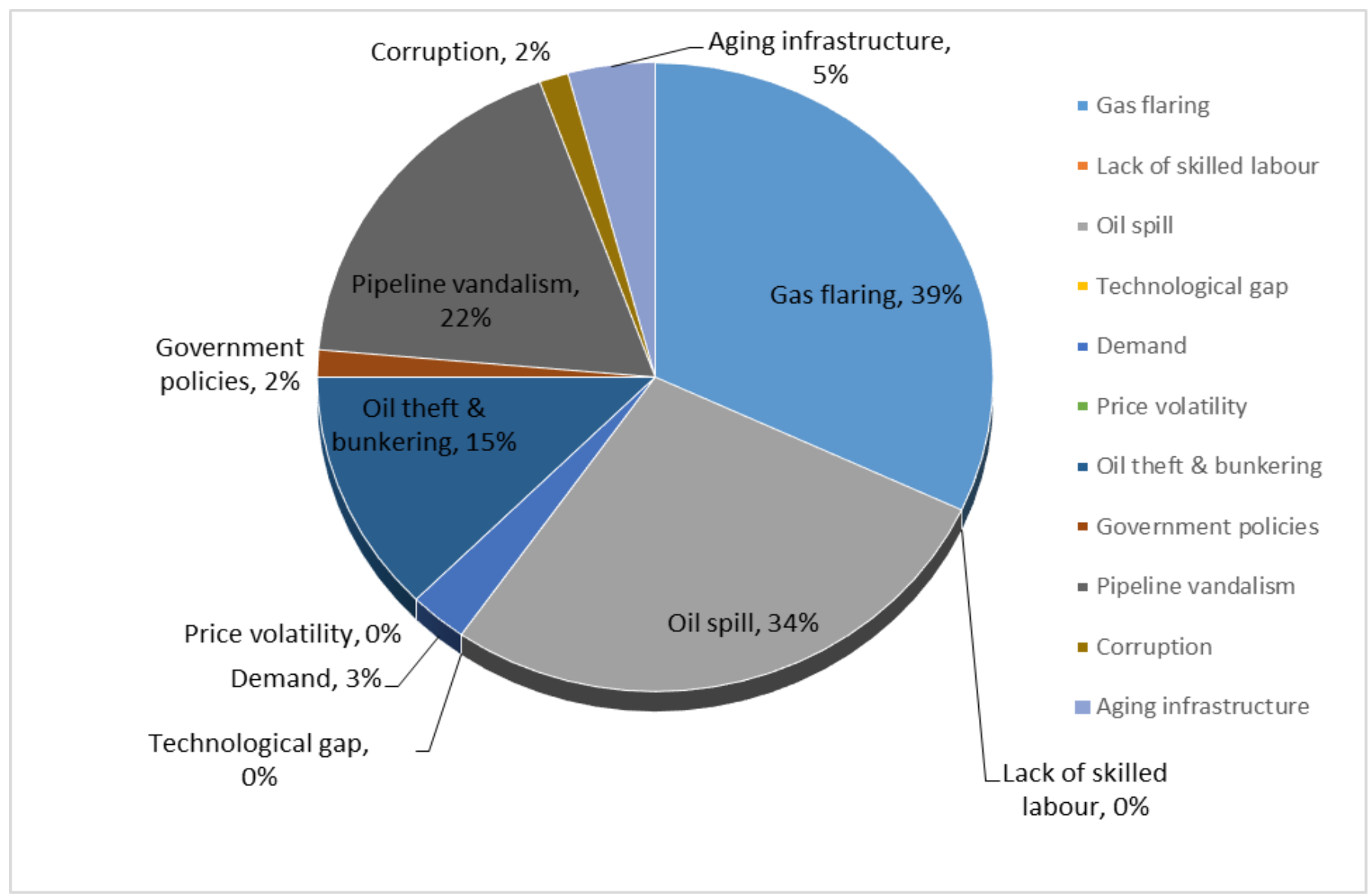

Figure 1: Summary of leaning of researchers on oil industry challenges in Nigeria from $2004-2015$

\section{EVOLUTION OF OIL INDUSTRY CHALLENGES IN NIGERIA}

A short history of the oil and gas industry in Nigeria is an epic narrative coloured with challenges in its operation, economic and enterprise of industry players. For over five and a half decades, the story has been that of transformational survival from one challenge to another. As a result, different challenge eras have evolved with each new one having links with the former. In this paper however, oil industry challenges in Nigeria would be categorized into three: The early years, the 'Wiwa' era and the $21^{\text {st }}$ century challenges. (a) The early years [1956 - 1989]: This period was mainly characterized by demand for refined petroleum products. Though this challenge still persists up till date, not much has been done to nip it in the bud. This challenge came from of the fact that the industry was still in its embryonic stage where it had to compete with coal as the major energy source.

(b) The 'Wiwa' era [1990-1998]: This era was dominated by the environmental degradation challenge. This was mainly oil spill and gas flaring related. Moved by the death of a major environmental activist in 1995 (Ogoninews online, 2015), a lot of newspaper columnists, environmentalists and Nigerian academic researchers rose to keep the challenge on 
the front burner. Much of work on environmental degradation emanating from oil company activities were seen between 1990 and 1998 [Olagoke, (1996), NDES, 1997, Saro-Wiwa, (1992), Benka-Coker and Ekundayo, (1995), Amadi et al. (1996)]. Most of these were mainly on oil spill in the Niger Delta. Figure 6 presents a gory sight of what oil spills has done to the environment in the Niger Delta. This struggle gave rise to yet a new set of challenges to the industry which were armed struggle, protests, vandalization of oil facilities and militancy. This era led to series of unending sanctions, litigations both at home and in the diaspora. A typical case is the unending legal tussle involving the people of Ogoni in Rivers state of Nigeria and Shell Petroleum Development Company of Nigeria. On the one hand, the struggles by the environmental and human rights activists led to the proliferation of social movements in Niger Delta such as the Movement for the Survival of Ogoni People (MOSOP) and later Ijaw Youth Council (IYC) in the early 1990s. There were other social movements that sprung up in this period such as the Urhobo Progressive Union (UPU), Isoko Development Union (IDU), Egbesu Boys of Africa (EBA), and Council for Ikwerre Nationality among others. More recently, the Movement for the Emancipation of the Niger Delta (MEND), the Niger Delta Volunteer Force (NDVF) and the Niger Delta Avengers among others are groups that also came up as a result of this. On the other side of the balance sheet, the Nigerian government in an effort to tackle the problem set up the Oil Mineral Producing areas Development Commission (OMPADEC) and much more recently the Niger Delta Development Commission (NDDC) and the Ministry of Niger Delta. All these are in a bid to stemming the tide of agitations by the communities of the Niger Delta region.

(c) The $21^{\text {st }}$ century challenges [2001 - Present]: This era has presented profound challenges that have ruptured the industry's economic fabric. This period is occasioned by challenges such as militancy, kidnappings and hostage taking of oil and gas workers, vandalism of oil and gas facilities, oil theft, illegal refineries, etc. This era was at its peak in 2006. The militancy and kidnappings started subsiding sometime in 2010 when the Nigerian government initiated and implemented the amnesty programme for the Niger Delta militants. New and frightening phenomena kept emerging during this era. As militancy died down, illegal oil bunkering, refining and crude oil theft kept this era busy.
The amounts of stolen crude hit an all-time high when a former minister of finance in Nigeria alleged that Nigeria was losing up to 400,000 barrels per day to crude oil theft (Ogbu, 2013). To further add to the frightening phenomena, there now exists the challenge of finding oil in unconventional and unfriendly terrains. Also, technological gap issues with the exploitation of the oil and gas as well as dwindling skill set available for work are calamities besieging this era.

\section{THE TOP ELEVEN CHALLENGES FACING THE INDUSTRY IN NIGERIA}

\section{Meeting the country's energy demands}

Since oil and gas remains the major energy source globally, without a doubt, the major parameter influencing the demand for oil and gas in Nigeria flows from the undeniable fact that the human population in Nigeria keeps growing at a rate of 3.2 percent according to National Population Commission, Nigeria, (NPC, online) as time keeps ebbing. The figure even as we speak now is increasing. This challenge was minimal during the late 1950s when oil production began in Nigeria but as time went by occasioned by both population and economic growth, this challenge metamorphosed from minimal to a maximum. Table 2 summarizes this. However, the real challenge here is that the crude that is produced from Nigeria is exported and then refined and sold back to the country. The marketers find it difficult to bring in products at low cost (landing costs, etc.) and even when they do, to distribute the products becomes a problem. This leads to the scarcity of the products and eventual skyrocketing of the prices when they are available. According to a study by Akpan and Nnamseh (2014), the recurring instances of petrol scarcity, usually worsens towards the end of the year. These grounds the transport industry as Nigerians stay in fuel queues for days to get the non-existent petroleum products as depicted in Figure 8. Again, the moribund and obsolete refineries in the country have been a major issue in meeting the demand for these refined products. Table 3 presents the production capacities of the three Nigerian refineries: Warri Refining and Petrochemical Company (WRPC); Kaduna Refining and Petrochemical Company (KRPC); and Port Harcourt Refining Company (PHRC) for the period of January 2015 to December, 2015

Table 2: Population and domestic consumption of oil in Nigeria

\begin{tabular}{|l|l|l|l|l|l|l|l|l|l|l|l|}
\hline Year & $\mathbf{1 9 9 1}$ & $\mathbf{2 0 0 6}$ & $\mathbf{2 0 0 7}$ & $\mathbf{2 0 0 8}$ & $\mathbf{2 0 0 9}$ & $\mathbf{2 0 1 0}$ & $\mathbf{2 0 1 1}$ & $\mathbf{2 0 1 2}$ & $\mathbf{2 0 1 3}$ & $\mathbf{2 0 1 4}$ & $\mathbf{2 0 1 5}$ \\
\hline $\begin{array}{l}\text { *Population (in } \\
\text { millions) }\end{array}$ & 88.92 & 139.8 & 143 & 146.9 & 150.7 & 151 & 159 & 164 & 166 & 174 & 179 \\
\hline $\begin{array}{l}\text { \#Consumption of } \\
\text { oil (thousands of } \\
\text { bbls/day) }\end{array}$ & 258.66 & 284.47 & 232.22 & 263 & 252 & 283 & 287 & 300 & 302 & NA & NA \\
\hline
\end{tabular}

\footnotetext{
* National bureau of statistics. http://www.tradingeconomics.com/nigeria/population

\# United States Energy Information Administration (2015)

$\mathrm{NA}=$ Not Available
} 
Table 3: Production capacity of Nigeria refineries (Jan. Dec., 2015)

\begin{tabular}{|l|l|}
\hline Refinery & Production Capacity (\%) \\
\hline WRPC & 7.01 \\
\hline KRPC & 4.62 \\
\hline PHRC & 2.95 \\
\hline
\end{tabular}

(Source: NNPC, 2015)

Interestingly, there are few Nigerians with big connections with refineries where our crude is being sold. They will ensure the status quo remains so that they can maximize profit from refined products importation and the so-called subsidy claims from the government.

Proposed Solution: Government should privatize the building of refineries in the country. At least four refineries for a start would be a nice way to begin. Moreso, most of the illegal refineries destroyed by the government uses crude equipment to refine crude oil. Therefore, instead of destroying these illegal refineries, the government can grant licenses and financial assistance for them to operate legally. Also, government should give licenses to private investors to build and run modular refineries. For the benefits of modular refineries, see Unachukwu (online).

\section{GAS FLARING}

Hardly is oil ever produced as a pure liquid. It usually comes as a mixture with natural gas more often than not being a major component. Gas flaring is essentially the burning off of natural gas produced during the production of oil as shown in Figure 4. In essence, this gas is considered as a waste product. According to Nigeria Gas Flare Tracker (online), gas has been flared in Nigeria since the 1950's. Nigeria flares 17.2 billion cubic metres of natural gas per year in conjunction with the exploration of crude oil in the Niger Delta (Ajugwo, 2013). In Nigeria, according to Ibitoye (2014), the gas flare-out date has been shifted several times since the first deadline of 1984, 2008, 2012 which also were not enforced and the most recent deadline being 2018. The deadline shifts have been mainly due to lack of adequate infrastructure on ground to achieve the flare-out, and the reluctance of the international oil companies to comply. Again, given the meager penalty for glaring, it has assumed an alarming dimension which perpetually light day and night skies across the oil region of Nigeria. (Tule, Online)

Proposed Solution: The truth is, oil companies involved in gas flaring wouldn't stop the flaring by just mere deadlines set by the government. They need to be pushed to do so. Hence, the penalty for flaring imposed on companies by the government should be enforced with each company flaring paying $\$ 20 /$ cubic feet of gas flared. For the companies, they should partner with industries requiring gas for power generation and deliver same free of charge to them. Cement producing industries such as Dangote cement, UNICEM etc. are possible industries requiring the gas. Also, the burden of proof should be that of the polluter, implying that in their quest for operating permits, they should prove that their operations are not harmful. Gas to liquids projects should be encouraged. Again, the use of natural gas in the synthesis of methanol is a viable option.

\section{AGING/DILAPIDATED ASSETS AND} INFRASTRUCTURE

The assets/infrastructures in the industry that are mainly affected by age are domiciled in the downstream sector namely the storage, refining, distribution and marketing facilities but topmost of them is pipelines. In Nigeria, thousands of kilometers of pipelines snake throughout towns, cities and villages. It is on record that the network of pipelines in Nigeria belongs to the Products and Pipelines Marketing Company (PPMC), a subsidiary of the Nigerian National Petroleum Corporation, (NNPC). These pipelines are the most economical means of transporting oil and gas. The big issue facing the pipeline system today is age; for example, in Nigeria, the majority of the oil/gas/liquid pipelines are 30 to 50 years old since the discovery of oil at Oloibiri in Bayelsa State of Nigeria. Most of the pipes were laid on the surface based on industry standards in the past (Edeko and Mbamalu, 2004) as shown in Figure 7. Over time, the assets have aged and have essentially become living- dead facilities leaving behind a laundry list of problems. Such problems include: increasing operating costs, and environmental pollution. The continuing demand for oil and gas will mean these aging systems will need to function safely and efficiently for many more years. The hostility of host communities is one factor that makes it difficult to change some of these aging facilities due to prolonged neglect of the communities by the operating companies and government.

Proposed Solution: Companies should concentrate more on their Corporate Social Responsibilities (CSR) to the communities, so that they can have free access to the facilities for routine services. Also, with the recent improvement in technologies, the government should ensure that the companies upgrade their facilities for efficient operations.

\section{CORRUPTION/GOVERNMENT}

\section{INEFFICIENCY}

Just a click of the phrase: "corruption in the oil industry in Nigeria" in Google generates over 1.2 million results in a split second. This shows the extent to which corruption affects the industry. This is one challenge that is so pervasive that there is absolutely no area of the industry that is not affected. It is of major concern to the Nigerian oil and gas territory with the government, the companies and the people trading blames at each other. On the government side, partisan and nepotic allocation of oil blocks, manipulated and secretive oil and gas contract bids, inflated contracts, misappropriation of proceeds from hydrocarbon resources, multiple regulatory agencies carrying out same functions parasiting on the companies for kickbacks (Federal Ministry of Environment, Ministry of petroleum resources, Nigerian National Petroleum Corporation, 
Department of petroleum resources, Niger Delta development commission, Natural resources Conservation Council, National Environmental Standards and regulations Enforcement Agency, Special State committee on Environment, National council on Environment) are all institutions that are set up in relation to gas flaring On the oil spill side, we have National oil spill detection Agency (NOSDRA), Department of Petroleum Resources (DPR), etc., All these regulatory agencies have similar duties which in most cases overlap thereby causing conflict between the institutions thus leading to weakness in enforcement of the laws giving rise to corruption. On the company's side, nonremittance of tax and royalties and lack of accurate hydrocarbon metering, shady and opaque recruitment processes are just a few of the many cases showing corruption in the oil and gas industry.

Proposed Solution: Government should streamline the number of regulatory agencies involved in oil and gas operations so that overlapping/clashing of functions would not give rise to redundancy and possible corruption by the agencies.

\section{OIL PRICE VOLATILITY}

According to economists, the price of any commodity is largely determined by the forces of demand and supply. The price of crude oil at any given time is not insulated from these forces. Hence, the uncertainty in the price of crude oil at any time is one major challenge the industry has had to grapple with. This challenge is among the most worrying since the profitability of the industry depends on it. On the one hand, when crude oil prices are high, industry players embark on more and more projects seeking to expand their frontiers. On the other hand, when the prices dip, the industry experiences a squeezing effect. The effect of this squeezing include: wreaking havoc on the profits of industry players, springing up a wave of strong pessimism in the minds of players in investing in future projects and ultimately, the loss of jobs by employees. These effects have a far more reaching effect on the economy of countries such as Nigeria that depends on oil for funding its budget. This stifles government spending translating to economic hardship for its citizens. It must be said however that the price of crude oil is based on global economics and not necessarily an individual country affair. Little wonder Olayele (2015) opined that energy prices are determined by a complex interplay of economics, geopolitics and technological changes. For this reason, it is safe to say that given the oil price dynamics, no man, model or prophet can predict what the price of crude oil will be three months, six months or a year from now. It could be $\$ 10$ or $\$ 120$ per barrel. The current fall of oil prices in the late 2015 due to the combined forces of over production/supply as well as new reserve finds in non-oil producing countries is another domino falling in the wrong direction. This has cemented panic and shock on the part of industry players and in countries like Nigeria whose budget depends largely on proceeds from crude oil.
Proposed Solution: Diversification of the nation's economy is the way to go. Before the advent of oil, agriculture was the main stay. More efforts should go into agricultural products for foreign earnings. Huge opportunities abound in tourism and culture, artifacts, and solid minerals, yet they remain untapped.

\section{PIPELINE VANDALISM}

In the $\mathrm{E}$ and $\mathrm{P}$ industry's economic and operational equation, Pipelines remain a critical parameter required to balance oil and gas production and distribution. Their role in the transportation, marketing and distribution of natural gas, crude oil, and refined petroleum products cannot be overemphasized. Though illegal, vandalism of pipelines regrettably have found their pride of place as an integral part of oil and gas operations in Nigeria. Literature is replete with countless volumes of crude oil stolen off the pipeline network and sold off the Nigerian coast due to pipe vandalism. This leads to revenue loss going by the figure of 400, 000 barrels of stolen crude, the country could loss as much as 6.2billion USD/year or $\$ 29.2$ trillion/year. According to Onuoha (2008) Pipeline vandalization refers to illegal or unauthorized activities that involve the destruction of oil pipelines to disrupt supply or the puncturing of oil pipelines to siphon crude oil or its refined products in order to appropriate it for personal use or for sale in the black market or any other outlet. It includes such acts as oil bunkering, breaking oil pipelines to siphon fuel, scooping fuel from burst oil pipes and the deliberate act of oil terrorism. All these are as shown in Figure 5.

Proposed solution: Gradual replacement of the pipelines with the depth of burial of pipes increased. Online monitoring of pipelines with physical security/monitoring around pipeline areas.

\section{CRUDE OIL THEFT \& ILLEGAL OIL BUNKERING}

This challenge is profound as it has reached frightening dimensions. According to Smith and Simon (2014), there exists an open air market for illegal crude operating off the Niger Delta called the Togo Triangle. In 2013, a new and frightening phenomenon emerged. It was revealed by a former minister of finance that Nigeria was losing up to 400,000 barrels per day to crude oil theft! This frightening challenge is largely inexplainable due to denials of collusion by security agencies and their assurances to stop the trend.

Proposed solution: The security operatives should be indigenes of the Niger Delta. In addition, the security operatives should be well motivated to carry out their duties. The youth of the host communities should be trained in skilled labour to prevent them from engaging in this unwholesome act. They should be enlightened to know that their activities cause oil spills and consequently environmental degradation. Oil spills resulting from their act of sabotage do not attract compensation. 


\section{ENVIRONMENTAL DEGRADATION FROM}

\section{OIL SPILL}

Oil spill has been part of Nigeria's oil and gas history consistently walking on all fours from 1956 up until now. The story has been the same. As more fields are discovered and production increases, so does spill increase. The works of early researchers such as Eniola et al. (1983), Olokesusi (1987) bear eloquent testimony to this. Since this has continued unabated, oil spillage in Nigeria has sparked a wave of controversy as to the main causes of it. As this controversy lasts, one fact is evident - whenever controversies arise, one major participant that usually arrives late is the truth. Little wonder the blame game continues. The companies, the government and the host communities keep trading blames. Instead of taking responsibility, each party tend to rationalize, excuse themselves, justify their actions or inactions, sidestep the issues and keep passing the blame tray. That's why we hear of spills occurring as a result of pipeline leakage due to age and corrosion, sabotage, vandalism, theft, spills during loading and transportation etc. All this happens with no one accepting culpability.

Proposed Solution: The Gulf of Mexico oil spill in 2010 in which British Petroleum (BP) was mandated to pay millions of dollars as compensation to the government of the United States with a mandate to clean up the environment is one viable way of minimizing oil spill. If Nigerian government could make the companies and individuals liable by paying through their nose and made to clean up the spill would help ameliorate the problem. If in the event of a spill, the BP oil spill example is a good reference. Here, almost 800 million litres of crude oil leaked into the Gulf of Mexico after a drilling rig exploded and sunk. Yet within months much of the contamination had disappeared. How was that possible? (Awake, 2015). This was possible through a scientific research that has shown that an array of marine bacteria can break down the long chain carbon molecules present in crude oil. This rod shaped bacteria is known as Alcanivorax borkumensis and relies heavily on oil to supply it with energy.

\section{DEARTH OF SKILLED MANPOWER}

Lack of skilled manpower is another critical challenge that the Nigerian oil and gas industry is facing. The truth is that there is a shortfall of skilled manpower in the continent. Therefore, explorers usually go beyond the shores of the continent shopping for skilled manpower - increasing the capital expenditure. The reason is not far-fetched. Simply put, there is no synergy between the academia and the industry leading to shortage of skilled manpower. Although research is an important part in oil and gas industry operations, more often than not, in Nigeria, it is often not assigned a high priority since its results come in the long term and not in the short term; hence the industry tends to downplay this important area. Little wonder Siregar et al. (2011) opined that although research is an essential part in oil and gas industry, it is not often considered a high priority since it does not deliver clear results in the short term, coupled with the insufficiency of time and available human resources. They further added that a mutual understanding between universities and the oil and gas industry to conduct joint research that would benefit both institutions is the right way to go. Again, even with an avalanche of willing researchers, there is always the limitation of funding. This brings to the fore the need for a mutual synergy between Nigerian Universities and the oil and gas industry in conducting researches based on real life field problems. To add to the worry, a disturbing phenomenon reared its ugly head; the unjust reward system for the stakeholders in the academia. This phenomenon is that of patronizing beauty pageantry competitions with millions of naira and posh car gifts while high fliers in the academia are rewarded with handshakes. This trend if not checked would not augur well with the future of the industry.

Proposed Solution: The need for a robust synergy between town and gown cannot be over flogged here. The incorporation and provision of practical industry software as part of school curriculum would essentially nip this in the bud. It isn't just enough to donate books and laboratory equipment, but also specialized software and training for teachers of the course. The industry needs to recognize that researches are better done with experienced personnel but best done in collaboration with the younger generation. Masters and $\mathrm{PhD}$ degree students with research interests relevant to the oil industry should be given real life field challenges by the companies through their partnership with Nigerian Universities. The opportunity should come with the students' ability to access funds from the companies.

\section{UNCONVENTIONAL RESERVOIR ISSUES/SCARCITY OF SUBSURFACE} INFORMATION

In a world where easy access to oil is no longer the norm and extreme exploration and production scenarios dominate, the petroleum industry is facing new and difficult technical challenges for complying with the growing global energy demand (Cocuzza et al., 2011). The scarcity of downhole information is one challenge which makes the risk associated with oil and gas-business-related projects significantly higher than in other industry sectors. Beyond this, oil and gas are no longer found in conventional terrains. Now oil and gas is now discovered in challenging and unconventional terrains. Little wonder FMC Technologies (2013) asserts that: "The low hanging fruit is long gone. Every day, it is more of a challenge to increase oil and gas recovery and production in aging and under producing fields and complex ones: arctic and ultra - deep subsea fields, tight sands, shale and thermal oil sands, High Pressure High Temperature (HPHT) wells, long distance, deep water complex pre - salt or lower tertiary formations". This is depicted in Figure 2. 


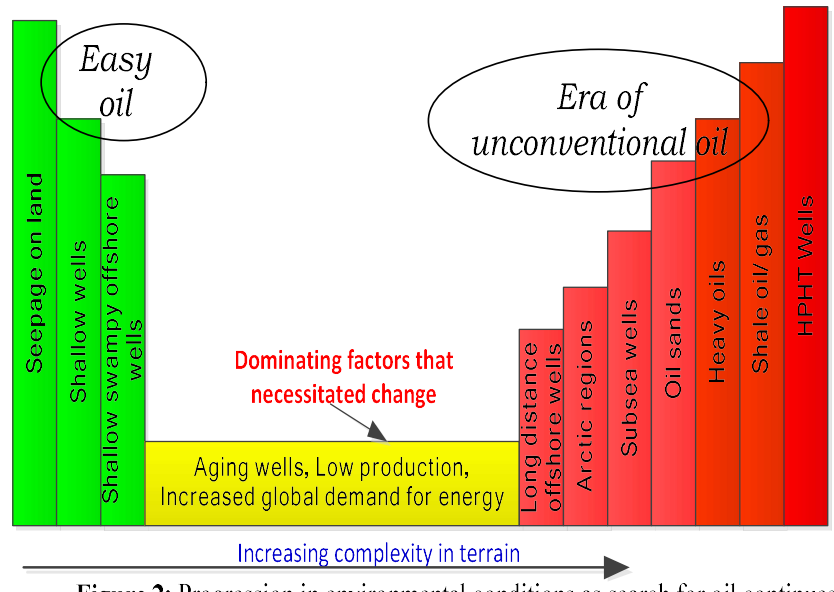

Figure 2: Progression in environmental conditions as search for oil continues

Reference: Brunei Darussalam has been producing oil and gas commercially for the past 80 years. Currently the country's oil production is on average 170,000 barrels per day (bbl/d) and 33 million cubic metres per day of gas. In terms of the country's income, it still accounts for 96 per cent of the country's main export. Like many other countries which have been producing oil and gas for years, Brunei Darussalam is also facing an era where there is no more easy oil. This has some impacts on the country's energy security. In facing the energy security challenges and its ability to continue extracting oil and gas from fields, technological advances have been embarked on. In the area of smart fields and drilling technologies, smart snake wells have enabled fields once dormant to be produced commercially. These wells are able to snake vertically and horizontally to tap into small and thin reservoirs while at the same time allowing the measurement and flow of separate sections. The snake wells have been able to produce what is usually achieved through the drilling of several individual wells, thus reducing cost. An example of this success is the Champion West field owned by Brunei Shell Petroleum (BSP). It lay dormant for 26 years since its discovery in 1975 but this changed when smart field and snake well technology was introduced and production began again in 2006. Smart fields are able to increase total recovery by 10 per cent for oil and 5 per cent for gas. Exploration programmes by companies have now been initiated in much deeper water situated further offshore. (Mohammad, Online).

Proposed Solution: The innovative snake well is one of the solutions which Shell engineers have come up with in order to improve access. Snake wells are so called because they can be drilled horizontally and 'snake' from one pocket of oil to another. Without the snake well, several individual wells would have to be drilled in order to access each pocket. The snake well significantly lowers the cost of drilling. (Science and Technology in Action, 2013)

\section{GOVERNMENT POLICIES/INTERFERENCE}

According to a study conducted by Akpata (2014), government interference is the factor that most severely hinders companies' attainment of operational excellence. According to him, it has been identified as the single most important reason for underperformance. In Nigeria, the issue of the controversial Petroleum industry bill (PIB) has made operators pessimistic as to how fair the bill would be on all stakeholders especially as it borders on current and future earnings as a result of reduced incentives, higher taxes and community development levies. Again, on the joint venture partnership agreement the government has with the companies, the inability of the federal government's representative - the Nigerian National Petroleum Corporation (NNPC) mostly constrained by budget limitations to meet its financial obligations in the Joint Venture (JV) agreement, this has been a source of worry for the industry players.

Proposed Solution: The government should stop the JV partnership and go into Profit Sharing Contracts or Production Sharing Contract (PSC) and be mindful of the policies they make. Government should give incentives to encourage operating companies.

\section{LEARNINGS FROM THE REVIEW}

The challenges in the Nigerian oil and gas industry has passed through many frontiers with each new foray moving seamlessly into the next, hence requiring the industry to keep pace with this dynamic state and learn fast with a view to cushioning their effects. As a result, the following are the learnings from these assessments:

1. That the oil and gas industry in Nigeria as well as other parts of the world is challenge oriented as summarized in Figure 3. While these challenges are immensely colossal and affect the economy of the industry's operations, they are not expected to be technically insurmountable. Hence a holistic approach as this work has presented is required to better understand the severity of the challenges.

2. That real challenges facing the oil industry in Nigeria keep recurring with little or no definite solutions proffered. Some of these challenges are time and weather related e.g. pipeline aging while some others are population and economic growth dependent e.g. oil demand and yet others may have a government policy colouration.

3. That the researches in this area have been voluminous with researchers tending towards focusing on just one or two challenges; with little or no solutions proffered by the researchers. Most works are mainly focused on the degradation of the environment through oil spills and gas flaring.

4. That the biggest challenge to the industry is uncertainty and risk. This arises from one, the uncertainty associated with finding the oil, the uncertainty surrounding the subsurface formations even when they are found, the uncertainty in the geopolitical climate as well as uncertainty in the prices of the oil at any given time.

5. That industry/academia collaboration is important. This will ensure technology transfer and would reduce capital flight through employment of expatriates. 


\section{CONCLUSIONS}

This work has presented an integrated picture of eleven major challenges facing the oil and gas industry in Nigeria. These challenges have evolved and taken various dimensions over time. In this work however, we have set out the current position, analyzed the challenges facing the industry in terms of technology, environmental impacts, government policies, oil price fluctuations and oil finding uncertainties, possible implications were considered as well as possible solutions proffered for the Nigerian oil and gas industry. On the basis of the above assessment; the following conclusions are drawn:

1. The above challenges represent only an infinitesimal fraction of concerns of this extremely complex industry. However, it provides an overview of possible challenges any interested party be it oil company or investment institution, needs to take into consideration while building its strategy.

2. There are some other challenges such as employees balancing work and family life, long term job security for employees, workplace safety among others. These challenges are mainly domiciled in the corporate social responsibility of the companies and may not have been amplified as much as they should have but they are worth taking note of since they affect the manpower of the various companies.

3. The identified challenges can be overcome through the institution and implementation of viable and workable socioeconomic policies; provision of critical infrastructures, strict adherence to the rule of law and reduction in corruption; and lastly, visionary and purposeful leadership.

4. Though the views presented in this work may be contentious owing to the fact that the authors may not have dealt exhaustively with all the challenges in the Nigerian oil and gas industry especially in selecting the top eleven, but the consolation is that we have used established workable solution references from other parts of the world to justify our position.

5. 5. The solutions proffered to the challenges in this work do not constitute 'magic formulas' that provides instant relief to the challenges. But by adopting them and localizing them to fit the Nigerian context would sure be the way to go.

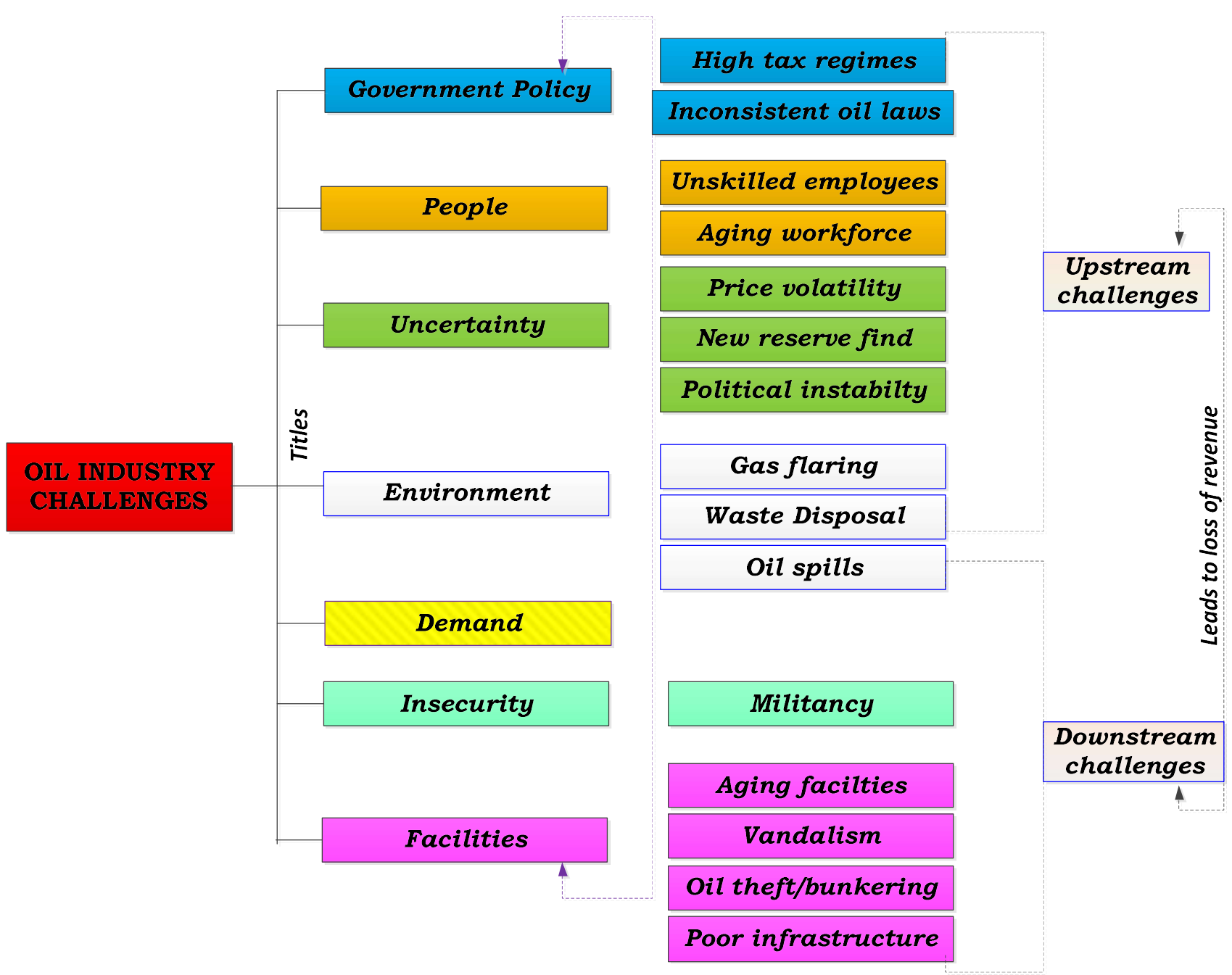

Figure 3: Summary of oil industry challenges in Nigeria \& their titles 


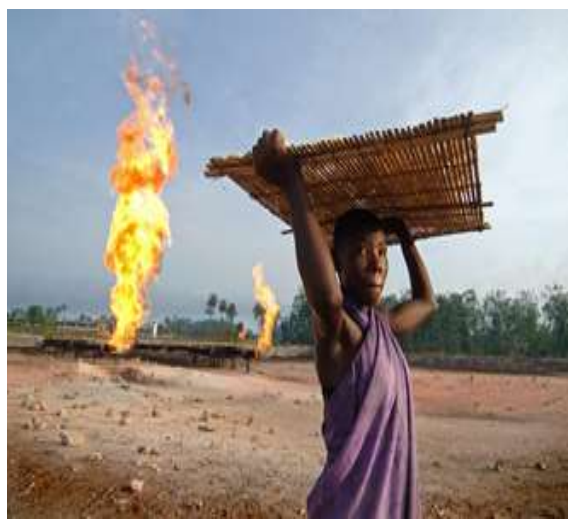

Figure 4: Gas flaring

(Source: http://www.gasflaretracker.ng)

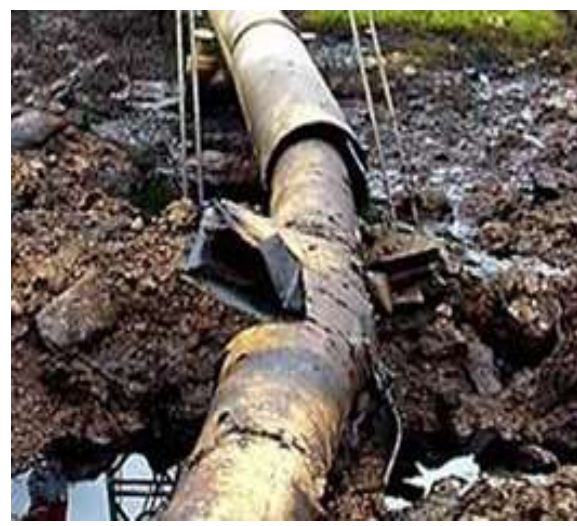

Figure 5: Vandalised Pipeline

Source: Eziukwu, 2015 in premiumtimesng.com

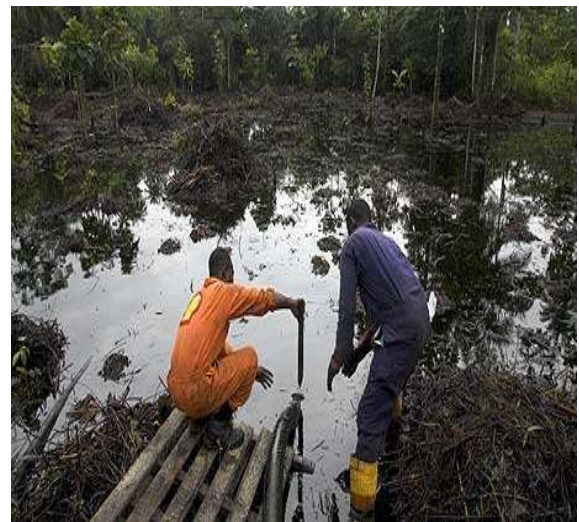

Figure 6: Oil Spill

(Source: Udo, 2013 in premiumtimesng.com)

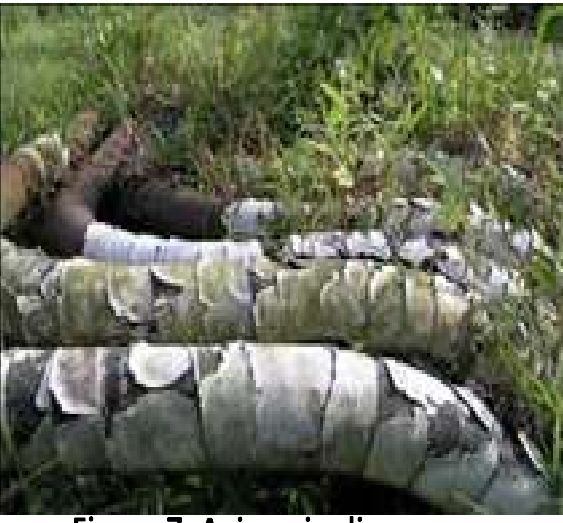

Figure 7: Aging pipelines

Source:premiumtimesng.com

\section{REFERENCES}

[1]. Achebe, C.H., Nneke, U.C. and Anisiji, O.E. (2012) Analysis of Oil Pipeline Failures in the Oil and Gas Industries in the Niger Delta Area of Nigeria. Proceedings of the International Multiconference of Engineers and Computer Scientists 2012 Vol. II, IMECS 2012, March 14 - 16, 2012, Hong Kong.

[2]. Abdulhakeem, S.O and Chinevu, A. (2014) Gas flaring in Nigeria; Impacts and Remedies. Paper SPE -170211MS presented at the SPE African Health, Safety, Security, and Environment and Social Responsibility Conference and Exhibition held in Maputo, Mozambique, 15-17 September 2014.

[3]. Adelana, S.O., Adeosun, T.A., Adesina A.O. and Ojuroye, M.O. (2011) Environmental pollution and remediation: challenges and management of oil Spillage in the Nigerian coastal areas. American Journal of Scientific and Industrial Research. Volume 2, Number $6 . \quad$ Pp.834 - 845. doi:10.5251/ajsir.2011.2.6.834.845

[4]. Adienbo, O.M. and Nwafor, A. (2010) Effect of prolong exposure to gas flaring on some haematological parameters of humans in the Niger Delta region of Nigeria. Journal of Applied Science and Environmental Management. Volume 14, Number 1. Pp $13-15$

[5]. Aghalino, S.O. (2009) Gas flaring, environmental

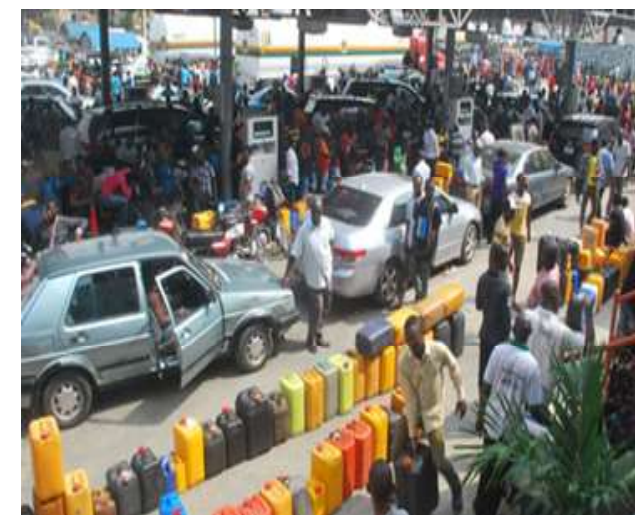

Figure 8: Fuel queue due to supply shortage Photo credit: Lamidi Bamidele in Vanguard Newspaper, Nineria

pollution and abatement measures in Nigeria, 1969 2001. Journal of Sustainable Development in Africa. Volume 11, Number 4.

[6]. Agwu, O.E. and Udoh, F.D. (2013) A pragmatic approach to a waste free oil and gas exploration and production activities in the Niger Delta region of Nigeria. Poll Res. Volume 32, Number 1, p. 1-15, EM International.

[7]. Ajugwo, A.O. (2013) "Negative Effects of Gas Flaring: The Nigerian Experience." Journal of Environment Pollution and Human Health 1.1 (2013): 6-8.

[8]. Akpan, S.S. and Nnamseh, M. (2014) Managing Risk of Petrol Scarcity in Nigeria: A Test of the Efficacy of Strategic Management Approaches. Global Journal of Human-Social Science: E Economics. Global Journals Inc. (USA). Volume 14 Issue 5 Version 1.0

[9]. Akpata, U. (2014) Review of the Nigeria oil and gas industry 2014. www.pwc.com/ng Alike, E. (2015) Ajumogobia Identifies Challenges in Nigeria's Oil and Gas Sector in THISDAYLIVE Newspaper. http://www.thisdaylive.com/articles/ajumogobiaidentifies-challenges-in-nigeria-s-oil-and-gassector/201607/

[10].Amadi, A., Abbey, S.D. and Nma, A. (1996) "Chronic effects of oil spill on soil properties and microflora of a rainforest ecosystem in Nigeria," Water, Air, and Soil Pollution, 86 (1-4). 1-11.

[11].Aroh, K.N., Ubong, I.U., Eze, C.L., Harry, I.M., Umo- 
Otong, J.C, Gobo, A.E (2010) "Oil spill incidents and pipeline vandalization in Nigeria: Impact on public health and Negation to attainment of Millennium development goal: the Ishiagu example", Disaster prevention and management: An international Journal, Volume 19 Issue1, pp.70-87

[12].Audu, E. B. (2013) Gas Flaring: A Catalyst to Global Warming in Nigeria. International Journal of Science and Technology. Volume 3, Number 1.

[13].Awake! (2015) Microorganisms that break down oil in Awake! Magazine. Watch Tower Bible and Tract Society of Pennsylvania. Volume 96, Number 9, September 2015.

[14].Ayoola, T. J (2011) Gas Flaring and it's Implication for Environmental Accounting in Nigeria. Journal of Sustainable Development Volume 4, Number 5.

[15].Babatunde, A (2010) Environmental Conflict and the Politics of Oil in the Oil-Bearing Areas of Nigeria's Niger Delta. Peace \& Conflict Review, Volume 5, Issue 1

[16].Badmus, I.A (2010) Oiling the Guns and Gunning for Oil: Oil Violence, Arms Proliferation and the Destruction of Nigeria's Niger-Delta. Journal of Alternative Perspectives in the Social Sciences. Volume 2, Number 1, p. 323- 363

[17].Bassey, N. (2001) "Oil and Gas in Africa". A paper presented at the Friends of the Earth International's (FOEI's) conference held in Cotonou/Ouida Benin Republic, 27 - 30 November 2000.

[18].Benedict, A.O (2011) Tragedy of Commons: Analysis of oil spillage, gas flaring and sustainable development of the Niger Delta of Nigeria. Journal of Sustainable Development, Volume 4, Number 2.

[19].Benka-Coker, M.O., and Ekundayo, J.A. (1995) "Effects of an oil spill on soil physico-chemical properties of a spill site in the Niger Delta Area of Nigeria," Environmental Monitoring and Assessment, 36 (2). 93-104.

[20].Boris, O.H (2015) The Upsurge of Oil Theft and Illegal Bunkering in the Niger Delta Region of Nigeria: Is There a Way Out? Mediterranean Journal of Social Sciences, MCSER Publishing, Rome-Italy. Volume 6 Number 3.

[21].Boyo, H. (2015) The recurring decimal of fuel queues in Vanguard Newspaper, November 23, 2015. www.vanguardngr.com

[22].Bradford, R.A (1995) Business Approach to Waste Management. Paper SPE 29703 prepared for presentation at the SPWEPA Exploration \& Production Environmental Conference held in Houston, TX, U, S.A., 27-29 March 1995.

[23].Brume, F. (2006) Oil pipeline vandalization in the Niger Delta: the way out http://wadoo.org/Environment/OilPipelines/BrumeOnP ipelineVandalization.html [accessed 02 January, 2016].

[24].Cazalot, C.P (2007) The Major Challenges Facing Our Industry. Marathon Oil Corp. Society of Petroleum Engineers. 0101-06-TT SPE Journal Paper.

[25].Chukwujeku, O.F., Chibuzor, A.S. and Ekene, O.F. (2014) Oil pipeline vandalism detection and surveillance system for Niger Delta Region. International Journal of Engineering Research and Technology, volume 3, Issue 7.

[26].Cocuzza, M., Pirri, F., Rocca, V., and Verga, F. (2011) Is the Oil Industry Ready for Nanotechnologies? Paper presented at the Offshore Mediterranean Conference and Exhibition in Ravenna, Italy, March 23-25, 2011.

[27].Donwa, P.A., Mgbame, C.O and Julius, O.M (2015) Corruption in the oil and gas industry: Implication for economic growth. European Scientific Journal, Volume 11, Number 22

[28].Edeko, F.O ad Mbamalu, J.E (2004) Issues and Challenges of Aging Pipeline coating infrastructure in Nigeria's oil and gas industry. NACE - 04178.Paper presented at NACE International Corrosion 2004 at New Orleans, Louisiana

[29].Effiong, S.A and Etowa, U.E (2012) Oil spillage cost, gas flaring cost and life expectancy rate of the Niger Delta people of Nigeria. Advances in Management \& Applied Economics, Volume 2, Number 2, 2012, pp. $211-228$

[30].Egbe, R. E. and Thompson, D. (2010) Environmental Challenges of Oil Spillage for Families in Oil Producing Communities of the Niger Delta Region. JHER Volume13, pp. 24-34

[31].Egwu, S.A (2012) Oil Spill Control and Management. Petroleum Technology Development Journal. January 2012 - Volume 1

[32].Eniola, O.A, Olusule, R. Agaye, G. (1983) Environmental and Socio Economic Impact of Oil Spillage in the Petroleum Riverine areas of Nigeria: In Proceedings of the International Seminar on the Petroleum Industry and the Nigeria Environment, (Lagos: NNPC).

[33].Etekpe, A. and Okolo, P.O (2010) Oil pipeline vandalization and the socio-economic effects in Nigeria's Niger Delta Region. SSRN Electronic Journal.

[34].Eziukwu, A. (2015) Shell snubs NOSDRA'S forum on mitigating pipeline vandalism in Premium Times Newspaper, August 25, 2015

[35].FMC Technologies (2013) Maximize recovery. Not someday. Now. Offshore Magazine. February, 2013, Volume 73, Number 2.

[36].Ibitoye, F.I (2014) Ending gas flaring in Nigeria's oilfields. Journal of sustainable Development. Volume 7, Number 3. Canadian Centre of Science and Education

[37].Igbinovia, P.E (2014) Oil thefts and pipeline vandalization in Nigeria. African Books Collective Publishers.

[38].Idris, R. O. (2007) Impacts of Oil Spillage and Gas Flaring On the Population and Distribution of Birds in Niger Delta Region of Nigeria. A Brief Interim Report Prepared Submitted to ABC Conservation Awards, ABC Conservation Fund United Kingdom. www.Africanbirdclub.Org.

[39].Imoobe, T.O.T and Iroro, T (2009) Ecological restoration of oil spill sites in the Niger Delta, Nigeria. Journal of Sustainable Development in Africa. Volume 
11 , Number 2.

[40].Imosemi, A and Abangwu, N (2013) Compensation of oil spill victims in Nigeria: The more the oil, the more the blood? Singaporean Journal of Business Economics and management studies Volume 2, Number 3, 2013

[41].Isa, A.H., Hamisu, S., Lamin, H.S., Ya'u, M.Z and Olayande, J.S (2013) The perspective of Nigeria's projected demand for petroleum products. Journal of Petroleum and Gas Engineering. Volume 4, Number 7, pp. 184-187

[42].Ite, A.E., Ibok, U.J., Ite, M.U., and Petters, S.W. (2013) Petroleum Exploration and Production: Past and Present Environmental Issues in the Nigeria's Niger Delta. American Journal of Environmental Protection, Volume 1, Number 4, pages $78-90$.

[43].Iwejingi, S.F (2013) Socio-Economic problems of oil exploration and exploitation in Nigeria's Niger Delta. Journal of Energy Technologies and Policy. Volume 3, Number 1.

[44].Kadafa, A.A (2012) Oil Exploration and Spillage in the Niger Delta of Nigeria. Civil and Environmental Research. Volume 2, Number 3.

[45].Kadafa, A.A., Zakaria, M.P and Othman, F (2012) Oil Spillage and Pollution in Nigeria: Organizational Management and Institutional Framework. Journal of Environment and Earth Science. Volume 2, Number 4.

[46].Kaladumo, C.O and Ideriah, T.J.K (2014) The environmental desiderata of gas flaring in the emerging oil and gas fields of Africa in the $21^{\text {st }}$ century: Lessons from Niger Delta region of Nigeria. Paper SPE172468-MS presented at the SPE Nigeria Annual International Conference and Exhibition held in Lagos, Nigeria, 5-7 August, 2014

[47].Lawal, M.O. and Ese, T.C (2012) Environmental Impact of pipeline vandalization on the Nigerian Landscape: The case of the Niger Delta Region. Journal of Human Ecology, Volume 39, Number 1, p. 73-84

[48].Livinus, A., Obah, B. and Akpan, S.E. (2014) Proposed Equations for Crude oil theft volume (And volumeshare) Estimation in oil transport pipeline network. Academic Research International. Volume 5, Number 5.

[49].Mohammad, P.D. H (Online) Development and the environment. World PetroleumNational Population Commission,

[50].Nigeria (Online) Nigeria Over 167 Million Population: Implications and Challenges. http://www.population.gov.ng/index.php/84 news/latest/106-nigeria-over-167-million-population implications-and-challenges. Accessed: $28^{\text {th }}$ October, 2015

[51].Nigerian Bureau of Statistics (online) Nigeria population http://www.tradingeconomics.com/nigeria/population. Accessed: 28 August, 2015

[52].Nigeria Gas Flare Tracker (online) About gas flaring. http://gasflaretracker.ng/about.html. Accessed: 28 August, 2015

[53].Nigerian National Petroleum Corporation (NNPC)
(2015) Financial and Operations Report: Monthly Report.

http://www.nnpcgroup.com/Portals/0/Monthly\%20Fina ncial\%20and\%20Operations\%20Data/Full\%20Reports/ NNPC $\% 20$ Monthly\%20Financial\%20and $\% 20$ Operatio ns $\% 20$ Report $\% 20$ for $\% 20$ the $\% 20$ month $\% 20$ of $\% 20$ Dec ember\%202015.pdf

[54].NDES, 1997: Niger Delta Environmental Survey; Final Report, Phase I. Environmental Resources Managers Limited. Nigerian Coastal Erosion and Subsidence, 1991: Technical Report NO. 1. Prepared for EEC/Nigerian Coastal Erosion Research Project. Ed. B.I.C Ijeoma. 137p

[55].Nkwocha, E.E and Pat-Mbano, E.C (2010) Effect of gas flaring on buildings in the oil producing rural communities of Rivers state, Nigeria. African Journal online. African Research Review. Volume 4, Number 2.

[56].Ntukekpo, D.S (1996) Spillage: Bane of Petroleum, Ultimate Water Technology and Environment.

[57].Nwanolue, B.O.G., Osegbue, C., and Iwuoha, V.C. (2013) The Nigerian state and crude oil bunkering in Niger-Delta: Examining the environmental vulnerability. African Journal of Social Sciences, Volume 3, Number 1. pp. $31-46$.

[58].Nwilo, P.C. and Badejo, O.T. (2005) Oil Spill Problems and Management in the Niger Delta. International Oil Spill Conference, Miami, Florida, USA.

[59].Ogbu, R. (2013) Nigeria loses revenue as 400,000 barrels of crude oil is lost daily - FG http://ynaija.com/nigeria-loses-revenue-as-400000barrels-of-crude-oil-is-lost-daily-fg/ Accessed: $29^{\text {th }}$ October, 2015.

[60].Ogoni News (2015) Landmark oil spill settlement has roots in execution of activist Ken Saro-Wiwa. http://www.ogoninews.com/ogoni/600-landmark-oilspill-settlement-has-roots-in-execution-of-activist-kensaro-wiwa/. Accessed: 30 ${ }^{\text {th }}$ December, 2015.

[61].Oguntuyi, O. (2014) The Challenge Of Maintaining Effective Security Against Vandalism. Paper presented at the $3^{\text {rd }}$ downstream conference. http://tandicebsolutions.com/rokdownloads/3rd Downstream Confe rence/Olufemi Oguntuyi.pdf

[62].Okafor, O. (2011) Environmental laws and factors affecting them in Nigeria. Case study of gas flaring laws in Niger Delta Nigeria. Msc Thesis report submitted to the Environmental Policy group, Department of Environmental Science, Wageningen University.

[63].Okoli, A. and Orinya, S. (2013) Oil Pipeline Vandalism and Nigeria's National Security. Global Journal of Human Social Science. Volume 13, Issue 5, Version 1.0 .

[64].Olagoke W., (1996): Niger Delta Environmental Survey: Which Way Forward? Ultimate Water Technology \& Environment

[65].Olayele, F.B (2015) The Geopolitics of Oil and Gas. International Association for Energy Economics Ologunorisa, T.E (2009) A review of the effects of gas 
flaring on the Niger Delta environment. International Journal of Sustainable Development \& World Ecology Volume 8, Issue 3, pages 249-255. doi: $10.1080 / 13504500109470082$

[66].Olokesusi, A.O. (1987): Characteristics of environmental problems in Nigeria and management prospects, The Environmentalist, 7(1): 55-60.

[67]. Oloruntegbe, K.O., Akinsete, M.A., and Odutuyi, M.O (2009) Fifty Years of Oil Exploration in Nigeria: Physico-chemical Impacts and Implication for Environmental Accounting and Development. Journal of Applied Sciences Research, Volume 5, Number 12.

[68]. Oluwatuyi, O. and Ileri, O.N. (2013) Petrol tanker disaster, pipeline vandalization and impacts on regional development in Nigeria. European Journal of Science and Engineering, Volume 1, Number 1, pp. 34 - 41

[69].Omeire, E.U., Aveuya, A.A., Muoneme-Obi, C.T., Gold, A., Akudo, U. and Omeire, C.A. (2014) Between the devil and the deep blue sea: Niger Delta women and the burden of gas flaring. European Scientific Journal Volume10, Number 26.

[70]. Onuoha, F.C. (2007) Poverty, pipeline vandalization/explosion and human security: integrating disaster management into poverty reduction in Nigeria. African Society Review, 16(2): 94-108

[71]. Onuoha, F.C (2008) Oil pipeline sabotage in Nigeria: Dimensions, actors and implications for national security. Essay in African Security Review Volume 17, Number $3 . \quad$ Pp.99-115. doi:10.1080/10246029.2008.9627487

[72]. Onuzuruike, V.I (2008) Oil bunkering in Nigeria's Niger Delta Region (1990-2007): (The trade, practice and economic implications). MBA Project submitted to the Department of Maritime Transport Management of the Federal University of Technology, Owerri.

[73]. Orimoogunje, O.O.I., Ayanlade, A., Akinkuolie, T.A., and Odiong, A.U. (2010) Perception on effect of gas flaring on the environment. Research Journal of environmental and earth sciences. Volume 2, Number 4, p. $188-193$

[74].Oshwofasa, B.O., Anuta, D.E., and Aiyedogbon, J.O. (2012) Environmental Degradation and Oil Industry Activities in the Niger-Delta Region. African Journal of Scientific Research Volume 9, Number 1.

[75].Oteh, C.O and Eze, R.C. (2012) Vandalization of oil pipelines in the Niger Delta Region of Nigeria and Poverty: An Overview. Studies in Sociology of science. Canadian Research and Development Centre of Sciences and Cultures. Volume 3, Number 2.

[76]. Oyefusi, A. (2014) Oil bunkering in Nigeria's post amnesty era: An ethnopoilitcal settlement analysis. Journal of Ethnopolitics. Volume 13, Issue 5.

[77].Raji, A.O.Y. and Abejide, T.S. (2013) An assessment of environmental problems associated with oil pollution and gas flaring in the Niger Delta region Nigeria, C.1960s-2000. Arabian Journal of Business and Management Review (OMAN Chapter) Volume 3, Number 3.

[78].Salako, A., Sholeye, O and Ayankoya, S. (2012) Oil spills and community health: Implications for resource limited settings. Journal of Toxicology and Environmental Health Sciences Volume 4, Number 9, pp. $145-150$.

[79].Saro-Wiwa, K. (1992), Genocide in Nigeria: The Ogoni Tragedy. Saros International Publisher, Port Harcourt, Nigeria. p.34

[80]. Science and Technology in Action (2013) Sparking the spirit of innovation: Technology to the rescue. Science and Technology in Action Sixth Edition http://editions.sciencetechnologyaction.com/lessons210368.php

[81].Siregar, S., Soekarno, D.P., Soewono, E., Mucharam, L., Sidarto, K.A., Gunawan, A.Y., Priharto, N. and Swadesi, B. (2011) Oil and Gas industry driven academic research. Paper SPE 148125 presented at the SPE Asia pacific oil and gas conference and exhibition held in Jarkata, Indonesia, 20 - 22 September, 2011.

[82].Smith, R., and Simon, J. (2014) How to steal a million barrels of oil. Planet money. NPR.

[83].Stegemeier, R.J. (1986) Current Challenges to the U.S. Petroleum Industry. Paper SPE-15850-MS presented at the SPE Annual Technical Conference and Exhibition, 5-8 October, New Orleans, Louisiana.

[84]. Tamuno, S and Felix, J.M. (2006) Crude Oil Resource: A Blessing or Curse to Nigeria - The Case of the Niger Delta. Journal of Research in National Development, JORIND Volume 4, Number 2. pp. 53-58

[85].Tule, M.K. (online) Environmental and host community issues in African oil exploration: the Niger Delta region of Nigeria. Paper presented at the $18^{\text {th }}$ World Petroleum Congress. Africa Session, Forum 24 paper

[86].Ubani, E.C and Onyejekwe, I.M (2013) Environmental impact analyses of gas flaring in the Niger Delta region of Nigeria. American Journal of Scientific and Industrial Research. Volume 4, Number 2, pp. $246-$ 252.

[87].Udoayang, J.O and Etowa, U.E (2013). The cost of oil spillage and gas flaring on the socio - economic development of the Niger Delta region of Nigeria. Research Journal of Finance and Accounting. Volume 4, Number 4.

[88].Udo, B. (2013) NOSDRA, HYPREP agree to partner on Ogoniland oil spill remediation in Premium Times Newspaper. www.premiumtimesng.com

[89].Udofia, O.O. and Joel, O.F. (2012) Pipeline Vandalism in Nigeria: Recommended Best Practice of Checking the Menace. Paper SPE 162980 presented at the Nigerian Annual International Conference and Exhibition held in Abuja, Nigeria. 6-8 August, 2012.

[90].Ufuoma, O. K. and Omoruyi, O. (2014) Political Economy Diagnosis of Crude Oil Theft in Nigeria: The Way Forward. Mediterranean Journal of Social Sciences. MCSER Publishing, Rome-Italy. Volume 5, Number 2.

[91].Ukala, E. (2011) Gas flaring in Nigeria's Niger Delta: Failed promises and reviving community voices, 2 Wash. \& Lee J. Energy, Climate \& Environment. 97 (2011), http://scholarlycommons.law.wlu.edu/jece/vol2/iss1/4 
[92].Unachukwu, E. (Online) Reducing dependence on imported fuel through promotion and investment in small and medium scale refineries. http://tandicebsolutions.com/rokdownloads/Summit/RefinerySummi tPaper2.pdf . Accessed: 28 August, 2015

[93].U.S. Library of Congress (online) Nigeria - Census History. http://countrystudies.us/nigeria/35.htm. Accessed: 28 August, 2015

[94].United States Energy Information Administration (2015) Nigeria Crude oil consumption by year. http://www.indexmundi.com/energy.aspx?country=ng \&product $=$ oil\&graph $=$ consumption. $\quad$ Accessed: 28 August, 2015

[95].Wilson, G. (2014) The Nigerian State and oil theft in the Niger Delta region of Nigeria. Journal of Sustainable Development in Africa. Volume 16, Number 1. 